\title{
OS DOIS LADOS DA MESMA MOEDA: \\ DEUS E O DIABO EM O EVANGELHO SEGUNDO JESUS CRISTO
}

\author{
Ronaldo Ventura Souza ${ }^{1}$
}

\begin{abstract}
Resumo: O objetivo deste ensaio é a análise da desmitificação das personagens Deus e Diabo no romance O Evangelho Segundo Jesus Cristo, de José Saramago. Diferentemente do modo como ocorre na tradição cristã, em que tais entidades míticas são colocadas em planos opostos e excludentes, como representações do Bem e do Mal, no romance, essas duas personagens aparecem como absolutamente necessárias uma a outra, como se fossem os dois lados de uma mesma moeda.
\end{abstract}

Palavras-chave: Personagem; Religião; Deus; Diabo; Saramago

\begin{abstract}
The objective of this essay is the analysis characters' desmitification God and Devil in the novel O Evangelho Segundo Jesus Cristo, of José Saramago. Differently in the way as it happens in the Christian tradition, in that such mythical entities are put in opposite and excluding plans, as representations of the Good and of the Evil, in the novel, those two characters appear as absolutely necessary to each other, as if they were the two sides of a same coin.
\end{abstract}

Keywords: Character; Religion; God; Devil; Saramago

\footnotetext{
${ }^{1}$ Mestre e doutorando em Literatura Portuguesa pela USP.
} 
"No princípio, Deus criou o céu e a terra" (Gen. 1:1). Eis o início da história do Deus judaico-cristão. A novidade, na história das divindades, é que este se quer único, seu berço é o berço do monoteísmo religioso. Consequentemente, o passo seguinte da tradição judaico-cristã foi transformar os outros deuses em criaturas demoníacas, os adversários do único e verdadeiro. É desse modo que, na cultura ocidental, origina-se uma luta entre o Bem e o Mal, em que essas antigas divindades de mitologias da Antiguidade do Oriente Próximo (caldeus, babilônios, persas, etc.) passam a ser os representantes do Mal, os demônios. Quem os lidera é a mesma serpente que tentou o primeiro homem e a primeira mulher, provocando a queda do gênero humano, figura que a tradição cristã tratou de identificar como Lúcifer, o "anjo de luz", que se rebelou contra o seu criador e "caiu do céu como um raio". Essa interpretação do relato mítico da criação da Bíblia levou séculos para chegar ao que hoje conhecemos, com Deus e o Diabo, os anjos e os demônios.

No entanto, essa tradição será revista de forma heterodoxa a partir do século XIX. Para o espírito racionalista da época, personagens como Deus e Diabo não passam de figuras míticas, de modo que ganham novas versões literárias. Na Literatura Portuguesa, por exemplo, podemos citar obras como $A$ Relíquia, de Eça de Queiroz, ou $A$ velhice do Padre Eterno, de Guerra Junqueiro. É dentro desse conjunto de textos, que poderíamos chamar de anticânone religioso, que se insere O Evangelho Segundo Jesus Cristo, de Saramago. E nosso objetivo, aqui, é a análise do processo de desmitificação das personagens Deus e Pastor (Diabo) nesse romance saramaguiano, que pode ser caracterizado como uma crítica contundente ao lado negro da história cristã que levou a martírios, Cruzadas, Inquisição, entre outras coisas.

\section{II}

Inicialmente, segundo Nogueira, o Deus judaico-cristão era apenas o deus tribal dos hebreus, superior aos deuses das tribos vizinhas que eram seus inimigos: "Agora conheci que o senhor é grande sobre todos os deuses (Ex. 15: 11)". Com o passar do tempo, a 
religião hebraica evoluiu para um monoteísmo absoluto, em que Deus é onipresente e onipotente criador de todas as coisas, cujo poder não pode ser desafiado; nesse estágio, os deuses das tribos vizinhas não passavam de ídolos vãos diante do único e verdadeiro Senhor dos Exércitos.

O Diabo, por sua vez, entra na história um pouco mais tarde. Para a tradição judaica do Antigo Testamento, o Diabo não existia. A idéia de Mal "é algo indefinido, ou seja, ele existe, mas não é incorporado em uma determinada personagem” (NOGUEIRA, 2000, p. 15). Mesmo em Jó, em que aparece a figura de Satã (cuja ação se resume em hostilizar, acusar, caluniar), a idéia de demônio ainda permanece pouco clara. É com o cristianismo que surge o anjo caído, o adversário de Deus, que se tornará a entidade do Mal, responsável por todas as tentações do homem (a tentação e queda de Adão e Eva, o condutor da adoração dos judeus ao bezerro de ouro, e assim por diante): a grandiosidade negada ao Diabo (Satã) pelo Antigo Testamento

será devidamente estabelecida pela literatura apócrifa e posteriormente reconhecida pelos Evangelhos e pelo Apocalipse de São João, onde Satanás assume o lugar de príncipe das trevas, responsável pela perdição do gênero humano. (NOGUEIRA, 2000, p. 22)

Frye pontua, em $O$ código dos códigos, que a partir da queda do homem se introduz uma:

metáfora jurídica que vai persistir ao longo de toda a Bíblia, segundo a qual a vida humana está em julgamento, com promotores e defensores. Nesta metáfora Jesus é o líder da defesa; o acusador chefe é Satã, o "diabolos", uma palavra da qual deriva a nossa "diabo", e que originalmente guardava o sentido de uma pessoa oposta à outra, num processo legal. (FRYE, 2004, p. 140)

Dentro deste contexto mítico, o Diabo, também chamado de Lúcifer, que significa “aquele que carrega luz", era um dos favoritos de Deus, a principal figura da corte celestial. No entanto, ele quis ser maior que Deus e tentou assumir o controle com o apoio de dois terços dos anjos (que formarão mais tarde a corte infernal, os demônios). Numa batalha épica, Lúcifer e seus seguidores foram derrotados pelo arcanjo Miguel, líder do exército divino, e precipitados do céu para as profundezas do abismo, o Inferno, que passou a ser 
governado pelo Diabo. As versões para o anjo caído normalmente se baseiam em trechos bíblicos não muito claros. Um deles, Isaías 14:12-15, diz o seguinte:

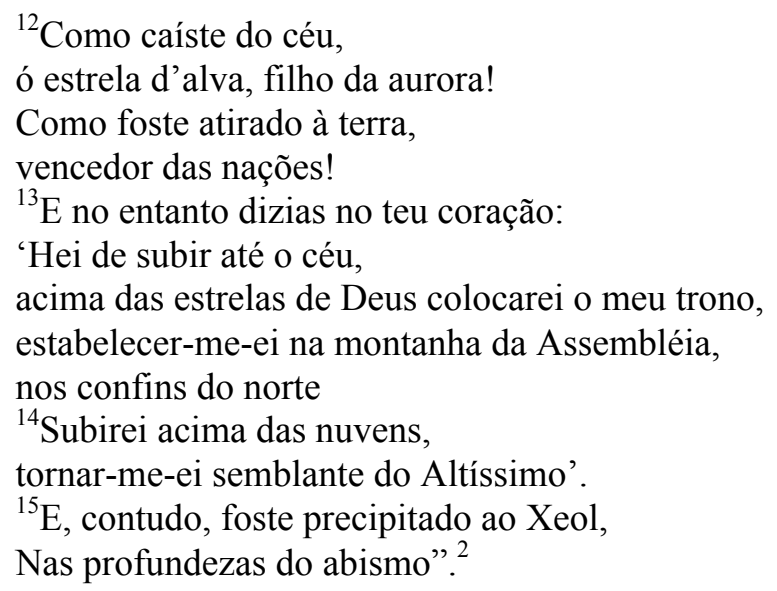

Tais versos parecem respaldar o mito sobre o Diabo da tradição cristã. Eles parecem se inspirar em um modelo fenício, apresentando vários pontos de contato com os poemas de Rãs-Shamra, em que a "estrela d'alva" e a "aurora" são duas figuras divinas e "a montanha da Assembléia" é o lugar onde os deuses se reuniam ${ }^{3}$. O primeiro verso de Isaías 14:12 é traduzido pela Vulgata como "Lúcifer, qui mane oriebaris, tornando o Deus caído chefe das legiões rebeldes" (NOGUEIRA, 2000, p.18), o Diabo, o príncipe dos demônios. Mas, se a presença do Diabo é de fato obscura no Antigo Testamento (a Bíblia hebraica), sendo muito mais fruto de leituras cristãs, é a literatura apócrifa e, posteriormente, os Evangelhos e o Apocalipse de São João que irão conceder a Satã a sua conhecida grandiosidade como o príncipe das trevas, responsável pela queda do homem e sua consequente expulsão do Paraíso terrestre. Segundo Nogueira:

Essa concepção da queda do Anjo Rebelde e do homem foi retomada pelos Padres da Igreja durante os séculos II e III e formalizada pela Igreja grega; um pouco mais tarde, Jerônimo (340-420) e Agostinho de Hippona (354-430) implantaram a mesma idéia na Igreja latina. Desse modo, no fim do século IV, tanto no Oriente como no Ocidente, os cristãos concordavam em que a queda do homem não foi mais que um episódio na

\footnotetext{
${ }^{2}$ Todas as citações de textos bíblicos neste trabalho foram retiradas da Paulus, 2001, $10^{\mathrm{a}}$ impressão.

${ }^{3}$ Bíblia de Jerusalém, nota 1, p. 1382. 
história de um prodigioso combate cósmico, iniciado antes da Criação, quando uma parte das falanges celestiais havia se revoltado contra Deus, sendo então precipitada dos céus. (NOGUEIRA, 2000, p.29)

No relato da criação, no Gênesis, Deus criou o homem a sua imagem e semelhança e, a partir da costela do homem, criou a mulher. Colocou-os num Paraíso terrestre e lhes permitiu tudo, exceto que comessem dos frutos da árvore do conhecimento do bem e do mal e da árvore da vida. O Diabo, que é, segundo a tradição cristã, a serpente do relato genesíaco, convenceu a mulher a comer do fruto proibido e oferecê-lo a Adão. É deste episódio mítico que resulta a queda do homem e, consequentemente, o surgimento do "pecado original", a origem de todos os males do mundo. Na literatura, O Paraíso Perdido, do escritor inglês John Milton, retoma esse episódio mítico, narrando o conflito entre Deus e o Diabo. Este se rebela contra o seu criador e é expulso do céu com seus seguidores, precipitado num abismo nos tempos primordiais, quando o mundo ainda não havia sido criado. Então, ciente de sua incapacidade de enfrentar Deus usando a força, Lúcifer se volta para o homem com o objetivo de destruí-lo e, assim contrariar a vontade do Pai celestial.

É desta forma que começa o embate entre o Bem e o Mal, Deus e o Diabo. Eles se encontram em planos diametralmente opostos da existência, representando o alto e o baixo, respectivamente, numa relação que poderíamos chamar de vertical. Um bom exemplo desta estrutura seria a Divina Comédia, de Dante, que segundo Frye, é, em certo sentido, uma obra mais religiosa que a própria Bíblia:

(...) a Comédia de Dante apresenta um Paraíso acima, um Inferno abaixo, e dois outros mundos na superfície deste nosso mundo. De um lado da Terra está a Itália do décimo terceiro, atarefadíssima na produção de Weltgeschite; do outro está a Montanha do Purgatório, onde as almas estão agrupadas unicamente em função do mundo eterno sobre elas, e onde o único "evento" histórico é sua passagem para este outro mundo acima. (FRYE, 2004, p. 75)

Assim, o poema de Dante é dividido em três partes, cada uma delas representando um plano da existência após a morte: Inferno, Purgatório e Paraíso. A primeira, governada pelo Diabo, que fica no último dos nove círculos do Inferno, recebe as almas dos pecadores, que não se arrependeram em vida; a segunda recebe as almas daqueles que se arrependeram 
pouco antes da morte e, por isso, ganham o direito de ascender ao céu depois de pagarem pelos seus pecados; a terceira, a morada de Deus, é a morada dos "justos", os nove círculos angélicos, o paraíso celestial.

Em O Evangelho Segundo Jesus Cristo, Deus e o Diabo já não estão em lados opostos, mas são necessários um ao outro, de forma que poderíamos dizer que ambos formam um espelho duplo, onde uma face reflete a outra: "Jesus olhou para um, olhou para outro, e viu que, tirando as barbas de Deus, eram como gêmeos, é certo que o Diabo parecia mais novo, menos enrugado, mas seria uma ilusão dos olhos ou um engano por ele induzido" (SARAMAGO, 2001, p. 368). Essa semelhança física pode ser um reforço dessa idéia do duplo entre os dois. O certo é que, ao contrário das escrituras, em que Jesus está em clara sintonia com Deus e oposto ao Diabo, no romance, o Diabo é seu primeiro professor, que tem manifesta influência em sua formação como o indivíduo que, mais tarde, será usado por Deus em seus planos de ser uma divindade adorada por mais gente do que a de um pequeno país no Mediterrâneo.

Deste modo, o romance, que pode ser caracterizado como uma paródia dos evangelhos, não apresenta a dualidade entre o Bem e o Mal comum nos textos bíblicos e na tradição cristã. Nestes há uma luta entre duas forças antagônicas da qual uma (o Bem) deve sair vitoriosa no final dos tempos com o surgimento de um novo céu e uma nova terra como é previsto no livro do Apocalipse. No romance, pelo contrário, Deus e Diabo têm que coexistir, a ausência de um leva ao desaparecimento do outro: "este Bem que eu sou não existiria sem este mal que tu és” (SARAMAGO, 2001, p. 392). É importante lembrar que o recurso mais comum usado neste diálogo com os textos sagrados e com a própria tradição cristã é o mecanismo da paródia, que segundo Linda Hutcheon, define-se como "repetição com distância crítica, que marca a diferença em vez da semelhança" (1985, p. 17), de forma que a "inversão irônica é uma característica de toda paródia" (Idem, p. 18). Assim, a história contada no romance carrega todas as marcas desta história arquiconhecida que, aparentemente, tem os sinais trocados, o negativo se torna positivo e vice-versa, num processo marcado por uma ironia incisiva e cáustica, mas o mais importante: a verdade absoluta do texto bíblico é relativizada; no romance, a palavra "verdade" está no plural. 
Consequentemente, a relação entre Deus e o Diabo em O Evangelho Segundo Jesus Cristo pode ser vista do ponto de vista de um mundo carnavalizado. Na obra, ocorre uma desconstrução deliberada da imagem divina que, de certo modo, vai se fundindo às características atribuídas, na tradição cristã, apenas ao Diabo e vice-versa. Neste romance saramaguiano, a nova face de Deus é a de um ser sanguinário e egoísta, pouco interessado pelos assuntos humanos: o que ele deseja é sua auto-satisfação, como veremos no encontro dele com Jesus e o Diabo no Mar da Galiléia. Em contraposição, o Diabo mostra interesse pela preservação da vida, seja ela qual for, imagem que contraria o modo como a tradição cristã o apresenta: o "inimigo", não apenas de Deus, mas da raça humana, cujo objetivo é levar quantos humanos puder para as profundezas do Inferno, que é o seu reino.

É possível verificar nessa relação Deus/Diabo no evangelho saramaguiano pelo menos duas categorias carnavalescas apontadas por Bakhtin: as mésalliances carnavalescas e a profanação. No primeiro caso, fica evidente a aproximação do elevado com o baixo: Deus equipara-se ao Diabo. Nesta equiparação, ficamos diante da profanação da tradição cristã, em que eles são figuras diametralmente opostas. No romance não há esse tipo de distinção, de forma que Deus e o Diabo estão no mesmo plano: não há menção a um novo paraíso, nem ao inferno, como ocorre nas sagradas escrituras, tudo acontece no mundo dos homens, resultando numa relação que poderíamos chamar de horizontalidade em oposição à verticalidade que marca o mito cristão.

\section{III}

No relato da concepção de Jesus temos a primeira manifestação de Deus no romance. Ele aparece como "puro espírito" como nos diz o narrador:

Deus que está em toda parte, estava ali, mas, sendo aquilo que é, um puro espírito, não podia ver como a pele de um tocava a pele de outro, como a carne dele penetrou a carne dela, criadas uma e outra para isso mesmo, e, provavelmente, já nem lá se encontraria quando a semente sagrada de José se derramou no sagrado interior de Maria, sagrados ambos por serem a fonte e a taça da vida, em verdade há coisas que o próprio Deus não entende, embora as tivesse criado. (SARAMAGO, 2001, p. 26) 
Sabemos que para a tradição cristã, Deus é onipresente, onipotente e onisciente. No começo da citação acima, o narrador nos chama a atenção para a primeira destas características: "está em toda parte”. Porém, as outras duas características são negadas: este Deus saramaguiano não é onipotente, pois "não podia ver", pelo fato de ser um "puro espírito"; e também não é onisciente, pois não entende as coisas que ele próprio criou.

Como podemos perceber, a figura de Deus passa por um processo de rebaixamento na obra. Se, na Bíblia, o poder do criador é sem limites, ou pelo menos nunca é questionado, no romance, esse poder será sempre colocado em questão. O fato é que este Deus saramaguiano não é muito diferente do que aparece na Bíblia, principalmente no Antigo Testamento. No entanto, todo comentário a respeito de Deus é sempre acompanhado de uma ironia cortante, de modo que a satisfação com o sacrifício de uma ovelha, que parece natural na narrativa do Gênesis ${ }^{4}$, é colocada no texto de Saramago como um atentado a uma vida. Assim, Deus acaba parecendo mais o "inimigo" do homem na história, papel relegado ao Diabo pela tradição cristã.

Nesta relação horizontal, Deus e Diabo aparecem com os papéis trocados: o Diabo é o Pastor, Deus é o "lobo". Vale lembrar a importância que tais metáforas têm no texto bíblico, em que Deus é o pastor que defende suas ovelhas (homem) do lobo (o "inimigo"). No romance, se Deus não é chamado de lobo, que aqui é a culpa, o Diabo, por seu turno, recebe o nome de Pastor, numa clara inversão de papéis em relação ao mito cristão.

$\mathrm{Na}$ verdade, o Deus saramaguiano não é diferente do bíblico, mas é o modo irônico como ele é apresentado no romance que provoca o seu rebaixamento aos nossos olhos. No relato bíblico de 2 Samuel 24, por exemplo, o rei Davi, incitado por Deus, resolve fazer o recenseamento do povo de Israel. O procedimento era um desrespeito às leis mosaicas, fato de que o rei só se deu conta depois. É claro que tal erro merecia um castigo e Deus enviou a Davi o profeta Gad com a proposta de três formas de castigo: três anos de fome, três dias de peste ou três meses de derrotas diante dos inimigos. O rei escolheu três dias de peste e o Senhor enviou um Anjo para cumprir a determinação divina, o que resultou na morte de setenta mil homens. O estrago só não foi maior porque Davi resolveu interceder e, em troca

\footnotetext{
${ }^{4}$ Em Gênesis 4, 16, Deus se mostra satisfeito com Abel por este lhe haver sacrificado ovelhas, ao mesmo tempo que fica descontente com Caim por ele haver lhe ofertado frutos da terra. Este é o motivo do primeiro homicídio, segundo este relato mítico.
} 
de um altar, o flagelo sobre o povo cessou. Em nenhum momento neste episódio bíblico o procedimento divino é questionado. Porém, no romance, ao lado de citações quase literais desse episódio, o narrador acrescenta comentários sempre irônicos:

Lá para o fim, o Senhor concordou em retirar a peste em troca de um altar, mas os mortos estavam mortos, ou foi Deus que não pensou neles, ou era inconveniente a ressurreição, se, como é de supor, muitas heranças já se estavam discutindo e muitas partilhas debatendo, que não é por certificarse um povo pertença direta de Deus que assim vai renunciar os bens do mundo, ainda por cima legítimos bens, ganhos com o suor do trabalho ou das batalhas, tanto faz, o que conta no fim é o resultado. (SARAMAGO, 2001, p. 139)

Enquanto Deus é este ser que demonstra indiferença pelo homem, o Diabo, como professor de Jesus, faz exatamente o contrário. Ele ainda é o tentador, que vai contra vários princípios da Lei mosaica:

Ouvide, ouvide ovelhas que aí estais, ouvide o que vos vem ensinar este sábio rapaz, que não é lícito fornicar-vos, Deus não permite, podeis estar tranqüilas, mas tosquiar-vos, sim, matar-vos, sim, comer-vos, pois para isso vos criou a sua lei, e vos mantém a sua providência. (SARAMAGO, 2001, p. 238)

O que Pastor sugere que Jesus faça é a prática da zoofilia que, segundo a Lei, deve ser punida com a morte do infrator. Vale lembrar que na metáfora bíblica do pastor e do 1 lobo $^{5}$, entre um e outro está a ovelha, que representa o homem. Assim, se pensarmos no que ocorre mais adiante no romance no episódio da barca, a palavra ovelha pode ser vista em seu sentido literal e em um sentido metafórico. O que importa, antes de tudo, é a defesa da vida, seja ela qual for, e a ironia aqui é que esta defesa é feita pelo Diabo. Assim, o homem continua a ser a ovelha indefesa diante do lobo, mas o pastor não é mais o mesmo.

Por outro lado, Deus é um ser egoísta e sanguinário, que se compraz com a morte de seres inocentes. Ao encontrar Jesus no deserto, ele exige o sacrifício de uma ovelha para o seu prazer, de certa forma, demoníaco, pois este seria uma característica do Mal:

Vá, despacha-te, tenho mais o que fazer, disse Deus, não posso ficar aqui eternamente. Jesus empunhou o cutelo, avançou para a ovelha que

\footnotetext{
5 Jo 10: 1-21.
} 
levantara a cabeça, hesitante em reconhecê-lo (...) Estás a chorar, perguntou Deus, Tenho os olhos sempre assim, disse Jesus. O cutelo subiu, tomou o ângulo do golpe, e caiu velozmente como o machado das execuções ou a guilhotina que ainda faltava inventar. A ovelha não soltou um som, apenas se ouviu, Aaaah, era Deus suspirando de satisfação. (SARAMAGO, 2001, p. 264)

A troca de papéis não significa apenas uma simples inversão, mais do que isso, acentua a natureza duplicada das duas personagens. Vale lembrar aqui que, em geral, as características de uma e de outra, no que diz respeito à tradição judaico-cristã, são mantidas, o que as modifica de fato é a ênfase. Por exemplo, o Deus do Antigo Testamento pode ser extremamente cruel até mesmo com o povo escolhido por ele, os exemplos são vários, como no já citado episódio do recenseamento feito pelo rei David. É sobre essa faceta de Deus que a narrativa do romance se concentra. Por outro lado, o Diabo não deixa de contrariar as "leis divinas", a citação acima é um exemplo disso, ele tenta levar Jesus a cometer um "pecado". No entanto, Pastor ganha características que antes eram atributos apenas de Deus que, na chamada "economia da salvação", sacrifica o próprio filho para o bem da humanidade. Tudo isso depende sempre do ponto de vista. No final das contas, dentro do romance, não existem nem o bem, nem o mal, já que ambos são uma única força que se duplica. O que pode ser o bem para um é o mal para o outro e vice-versa, daí as palavras de Pastor: "Sim, se Deus existe terá de ser um único Senhor, mas era melhor que fossem dois, assim haveria um deus para o lobo e um deus para a ovelha, um para o que morre e outro para o que mata, um deus para o condenado, um deus para o carrasco" (SARAMAGO, 2001, p. 233). É possível que a própria contradição interna da idéia de um deus monoteísta gere, no romance, a presença obrigatória de um diabo como uma duplicata de Deus. Em $O$ Códigos dos códigos, Frye levanta o problema que, segundo ele, seria "digno de um enxadrista, da teodicéia, ou de como fazer derivar um mundo mau de um bom Deus, sem que este seja responsável pela maldade (FRYE, 2004, p. 144)”. Como vemos, o problema crucial e de difícil solução está no fato de o mundo ser o que é, sendo criação de Deus que, religiosamente falando, é “bom”. Mesmo a idéia de pecado original não se mostra suficiente para explicar tal contradição, pois sendo Deus o criador de todas as coisas, implica que ele também criou o "mal" que assola a humanidade. Além do fato de que muitos pontos da história podem ser vistos em um contexto duplo, como observa Frye: 
"uma imagem demoníaca, no sentido de ser uma imagem da ira e da vingança divinas, ou uma imagem de salvação, dependendo do ponto de vista de que se o olhe" (FRYE, 2004, p. 180). Parece-nos, então, que esta contradição se traduz no romance pela relação dupla entre Deus e o Diabo, semelhante ao que ocorre em Dostoievski, que "procurava converter cada contradição interior de um indivíduo em dois indivíduos para dramatizar essa contradição e desenvolvê-la extensivamente" (BAKHTIN, 2008, p. 32). Assim, no romance, o Diabo seria um desdobramento de Deus ou vice-versa.

\section{IV}

É no encontro entre Deus, Jesus e Pastor, no mar da Galiléia, que o Deus-Pai, inescrupuloso e egoísta, enfim, revela sua sede de poder. Nesse diálogo, ele manifesta suas reais intenções expansionistas, e toda dor e sofrimento que seu modelo monoteísta acarretará na institucionalização da fé cristã às gerações futuras. Segundo Horácio Costa, há nesse diálogo "um confronto arquetípico pai-filho dentro de um contexto mítico. Estas alterações na realização da história de Cristo e a simultânea intimidade textual do romance com o cânone criam uma narrativa em que o processo de escrita como reescrita supera a crítica irônica e propicia um nível poético de incorporação da tradição"6 (COSTA, 1996, p. 195).

A "extraordinária novidade de um nevoeiro impróprio da época do ano" (SARAMAGO, 2001, 363) marca o encontro decisivo entre Deus, Jesus e o Diabo. Fato que já ocorreu antes na narrativa, a presença de Deus, ou às vezes do Diabo, é marcada por algum fenômeno extraordinário: no dia da concepção de Jesus, José viu um céu que nunca tinha visto na vida, que relacionou com mostras do poder divino, e Deus esteve presente na concepção como "puro espírito".

Deus surge na barca não como um "puro espírito", nem como uma coluna de fumo, que nos remete diretamente ao seu encontro com Moisés no Êxodo. Quem surge na barca é

\footnotetext{
${ }^{6}$ Tradução livre do trecho em inglês: "an archetypal father-son confrontation in a mythical context. These alterations in the rendition of Christ's story and the simultaneous textual closeness of the novel to the canon create a narrative in which the process of writing as re-writing surpasses derisive criticism and propitiates a poetical level of incorporation of the tradition".
} 
"um homem grande e velho, de barbas fluviais espalhadas sobre o peito, a cabeça descoberta, o cabelo solto, a cara larga e forte, a boca espessa, que falará sem que os lábios pareçam mover-se" (SARAMAGO, 2001, p. 364), vestido como um judeu rico. Deus está completamente antropomorfizado. Vale lembrar que, na narrativa bíblica, ele sequer pode ser visto por olhos humanos: o relacionamento dele com seus escolhidos se dá sempre por meio da palavra, a ênfase é o ouvir. No evangelho saramaguiano, pelo contrário, a visão é mais importante. A descrição que o narrador faz do aspecto de Deus e das suas vestes é impensável no texto bíblico. O modo como ele se apresenta a Moisés e aos Filhos de Israel no Êxodo é mais próximo da sua primeira aparição a Jesus no deserto, como uma coluna de fumo: "O aspecto da glória de Iahweh era, aos olhos dos filhos de Israel, como um fogo consumidor no cimo da montanha" (Ex, 24:17). Assim, o Deus do Antigo Testamento é aquele que não pode ser visto e cuja palavra é de todo modo incontestável, "a pretensão de verdade da Bíblia (...) exclui qualquer pretensão (AUERBACH, 2004, p. 11)". O Deus de Saramago, por outro lado, está em um mundo onde, como já dissemos, toda verdade é relativizada. Em outras palavras, primeiro ele surge como o inefável "puro espírito", que remete à voz do relato mítico da criação; depois, como uma coluna de fumo, ainda semelhante ao texto bíblico, cujo rosto não se pode ver, mas se ouve a voz potente e autoritária; e, por último, como um homem, a quem se pode ver. No relato bíblico predomina o ouvir ${ }^{7}$, no romance o ver, de modo que Jesus, um homem na obra, pode ver o rosto de Deus. Ironicamente, esta possibilidade é também o motivo de sua morte.

A primeira impressão que Jesus tem do surgimento do Diabo na barca é típica do imaginário cristão, que sempre o descreve com formas horrendas: "a imaginação de Jesus julgou ver um porco com as orelhas esticadas fora da água, mas que, após umas quantas braçadas mais, se viu ser um homem ou algo que de homem tinha todas as semelhanças" (SARAMAGO, 2001, p. 367). No final das contas, ele é o leviatã, monstro marinho do caos

\footnotetext{
${ }^{7}$ Em O Código dos códigos , Frye observa que há "uma característica na Bíblia de grande importância, considerando-se seu aspecto revolucionário: sua ênfase vigorosa nas metáforas do ouvido, em comparação com as metáforas da visão. Muito se diz sobre a palavra de Deus, e não há nenhum problema sobre a fala de Deus. Mas qualquer sugestão de que Deus foi visto merece expurgos ou é tratada editorialmente com grande ansiedade: em geral a explicação que acompanha o problema é a de que o "visto" era um anjo apenas" (FRYE, 2004, p. 146).
} 
primitivo, cujas origens remontariam à mitologia fenícia, que surge das águas e que no mito bíblico encarna a resistência a Deus.

Como vemos, instaura-se, no evangelho saramaguiano, o mundo às avessas do carnaval. Deus e Diabo são extremamente parecidos, como se fossem gêmeos, e como veremos mais adiante nesse diálogo da barca, a ligação entre ambos é muito mais profunda. O que podemos perceber neste capítulo é a natureza dupla dessas duas personagens, em que a semelhança física é apenas o fio da meada. $O$ fato central aqui é que um não pode existir sem o outro, para que Deus seja o que é ele, depende do seu duplo, o Diabo:

(...) Não me aceitas, não me perdoas, não te aceito, não te perdôo, querote como és, e, se possível, ainda pior do que és agora, Porquê, Porque este Bem que eu sou não existiria sem este Mal que tu és, um Bem que tivesse que existir sem ti seria inconcebível, a um tal ponto que nem eu posso imaginá-lo, enfim, se tu acabas, eu acabo, para que eu seja o Bem, é necessário que tu continues a ser o Mal, se o Diabo não vive como o Diabo, Deus não vive como Deus, a morte de um seria a morte do outro (SARAMAGO, 2001, p. 392-3).

Deste modo, a imortalidade de Deus só é possível com a existência do Diabo, o que nos leva à teoria de Otto Rank, segundo o qual o duplo tem o poder de concorrer para o impedimento da morte de si mesmo ${ }^{8}$. Assim, no mundo carnavalizado de O Evangelho Segundo Jesus Cristo, o Diabo é o duplo de Deus, a entidade imprescindível para que a divindade cruel e sanguinária do romance leve a cabo seus planos de expansão pelo mundo. Enfim, eles são os dois lados de uma mesma moeda. A natureza dupla de Deus e Diabo fortalece a desmitificação do texto bíblico que se opera no romance: a luta entre o Bem e o Mal que sustenta o mito já não se justifica como tal, porque ambos são engrenagens imprescindíveis de um mesmo sistema.

\footnotetext{
${ }^{8}$ Definição retirada de CEIA, Carlos (org). E-Dicionário de termos literários. Verbete "Duplo".
} 


\section{Bibliografia}

A Bíblia de Jerusalém. São Paulo: Paulus, 2001, 10ª Impressão.

ALTER, Robert \& KERMODE, Frank (orgs.). Guia Literário da Bíblia. São Paulo: Editora UNESP, 1997.

AUERBACH, Erich. “A cicatriz de Ulisses”, in: Mímises - A representação da realidade na literatura ocidental. São Paulo: Perspectiva, 2004, p. 1-30.

CUNHA, Carla. "Duplo", in: E-Dicionário de termos literários. Endereço eletrônico: http://www2.fcsh.unl.pt/edtl/verbetes/D/duplo.htm

COSTA, Horácio. "The fundamental re-writing: religious texts and contemporary narrative. Gore Vidal's Live from Golgota, Salman Rushdie's The satanic verses, José Saramago's $O$ Evangelho Segundo Jesus Cristo". Poligrafias - Revista Portuguesa de Literatura Comparada, n. 1, p. 189-98.

ELIDADE, Mircea. Mito e Realidade (Póla Civeli, trad.). São Paulo: Perspectiva, 2004. . O Sagrado e o Profano - A essência das religiões. Trad. Rogério Fernandes, São Paulo: Martins Fontes, 2001.

FRYE, Northrop. O Código dos códigos - A Bíblia e a literatura. Trad. Flávio Aguiar, São Paulo: Boitempo Editorial, 2004.

NOGUEIRA, Carlos Roberto. O Diabo no imaginário cristão. Bauru: Edusc, 2000.

SARAMAGO, José. O Evangelho Segundo Jesus Cristo. São Paulo: Companhia das Letras, 2001. 